\title{
Experimental Tree Planting on U.K. Containment Landfill Sites: Results of 10 Years' Monitoring
}

\author{
Andy Moffat, Kirsten Foot, Fiona Kennedy, Martin Dobson, and Geoff Morgan
}

\begin{abstract}
A series of experiments was set up in England in the early 1990s on five containment landfill sites engineered to modern standards to test the relative performance of 14 native and nonnative woodland tree species. This article describes the results of monitoring their survival, growth, and nutrition over a 10-year period. The experiments demonstrated that several species, notably ash, whitebeam, white poplar, and wild cherry, can usually be established on landfill sites with survival rates comparable to other brownfield sites. Despite general site infertility, growth of many tree species (for example, ash, beech, English oak, sycamore, Italian alder, silver maple, white poplar, and whitebeam) was similar to that expected on greenfield sites in the locality of the landfill sites. As well as infertility, soil droughtiness and mammal browsing were identified as limiting tree performance of particular species on some sites. After 10 years, there was no evidence of interaction with landfill containment systems or landfill gas.
\end{abstract}

Key Words. Landfill; nutrition; tree growth; tree species; tree survival.

The establishment of some form of vegetation is a vital part of the restoration strategy for landfill sites in many parts of the world (Department of the Environment 1996; California Integrated Waste Management Board 1999; Environmental Protection Agency 1999; Office of Superfund Remediation and Technology Innovation 2006). The choice of vegetation is especially important because it affects the appearance of the site and the way it fits into the wider landscape. Early guidance issued by the U.K. Department of the Environment (Department of the Environment 1986) actively discouraged tree planting on capped landfill sites. Principal concerns have included 1) the perception that tree roots could penetrate through an engineered landfill cap, allowing water ingress or escape of landfill gas; 2) shallow rooting resulting from the presence of dense soil layers or cap material may lead to drought and windthrow susceptibility; and 3) woodland establishment might disrupt or compromise landfill pollution control measures if the trees were to blow over. In addition, tree survival and performance were considered to be adversely affected by many landfill site conditions.

The U.K. Forestry Commission Research Division (now Forest Research) conducted an extensive desk review of The Potential for Woodland Establishment on Landfill Sites in 1993 (Dobson and Moffat 1993), which evaluated the likely patterns of tree root growth on landfill sites, the ability of tree roots to penetrate a landfill mineral cap, whether trees on these sites would be at risk from windthrow, and whether trees can actually grow on the comparatively harsh conditions of the landfill environment. The findings of the 1993 study suggested that it was possible to establish trees on modern containment landfills provided the sites were engineered to a standard suitable for effective pollution control, the landfill cap was well compacted (bulk density greater than $1.8 \mathrm{~g} / \mathrm{cm}^{3}$ ), and there was sufficient thickness of soil to prevent the threat of tree root penetration into the cap beneath.

However, the findings of the desk study were drawn from research not directly involving the landfill environment, because pre-1986 guidance had effectively prevented tree planting on recent landfill sites. The then Department of the Environment and its successors, now the Department of Communities and Local Government, has funded a program of study since 1993 to establish and monitor field experimental plots on landfills that had been constructed close to the specifications identified by Dobson and Moffat (1993). This article presents the results of the field-based experiments into tree performance monitoring on the five landfill sites, which have now been monitored for 10 years.

\section{MATERIALS AND METHODS}

A screening process was used to evaluate the characteristics of a large number of landfill sites identified by the Environmental Services Association and U.K. Waste Licensing Authorities. To select appropriate sites for the study, essential criteria were the presence of an engineered clay cap, an uncompacted soil cover with a minimum thickness of $1 \mathrm{~m}(3.3 \mathrm{ft})$, and a range of soil types and climatic conditions to be represented. The sites chosen were located at Bristol (Yanley), Swindon (Shaw Tip), Skelmersdale (Pimbo), Hatfield (Beech Farm), and Ely (Grunty Fen). Site locations and characteristics are summarized in Table 1.

Reclamation and woodland establishment practices at the sites followed, as closely as possible, the recommendations in The Potential for Woodland Establishment on Landfill Sites (Dobson and Moffat 1993). Most sites had soil or soil-forming materials placed by "loose tipping" (Bending et al. 1999) to reduce the risk of soil compaction, although ripping was used to alleviate compaction at Beech Farm. All sites except Shaw Tip were provided with some recycled topsoil material, although this was usually of limited thickness and of likely poor quality compared with standard definitions (British Standards Institution 1994).

Eight tree species were planted (total 1,152 trees) at each site in individual species plots of 36 trees. Species plots were replicated four times in a randomized block experimental design (Pearce 1976). Tree species were chosen from a list recommended by Dobson and Moffat (1993) with consideration given 
Table 1. Details of the five experimental sites.

\begin{tabular}{|c|c|c|c|c|c|}
\hline & Beech Farm & Grunty Fen & Pimbo & Shaw Tip & Yanley \\
\hline Latitude and longitude & $51.78 \mathrm{~N}, 0.26 \mathrm{~W}$ & $52.40 \mathrm{~N}, 0.20 \mathrm{E}$ & $53.53 \mathrm{~N}, 2.74 \mathrm{~W}$ & $51.57 \mathrm{~N}, 1.83 \mathrm{~W}$ & $51.43 \mathrm{~N}, 2.64 \mathrm{~W}$ \\
\hline National grid reference & TL 200100 & TL 497798 & SD 512040 & SU 122858 & ST 556698 \\
\hline Altitude (m O.D.) & 80 & 13 & 105 & 100 & 20 \\
\hline Annual rainfall (mm) & 675 & 550 & 900 & 700 & 900 \\
\hline Windiness (DAMS) score ${ }^{\mathrm{z}}$ & 12 & 12 & 13 & 12 & 10 \\
\hline Soil and soil-forming materials & $\begin{array}{l}\text { Sandy loam topsoil } \\
\text { and subsoil }\end{array}$ & $\begin{array}{l}300 \mathrm{~mm} \text { clay topsoil } \\
\text { over clay subsoil }\end{array}$ & Imported, various & Coral Rag limestone & $\begin{array}{l}100 \mathrm{~mm} \text { topsoil over } \\
\text { Keuper Marl }\end{array}$ \\
\hline Ground preparation & $\begin{array}{l}\text { Complete cultivation } \\
\text { to } 1.0 \mathrm{~m} \text { using } \\
\text { excavator }\end{array}$ & $\begin{array}{l}\text { Complete cultivation } \\
\text { to } 1.0 \mathrm{~m} \text { using } \\
\text { excavator }\end{array}$ & Loose tipping & Loose tipping & $\begin{array}{l}\text { Complete cultivation } \\
\text { to } 1.0 \mathrm{~m} \text { using } \\
\text { excavator }\end{array}$ \\
\hline Soil thickness (m) & 1.0 & 1.0 & 1.5 & 1.5 & 1.5 \\
\hline Topsoil $\mathrm{pH}^{\mathrm{y}}$ & $6.9-7.2$ & $7.3-8.1$ & $8.0-8.7$ & 8.3 & $8.0-8.3$ \\
\hline Topsoil organic carbon (\%) & 1.8 & 3.7 & 1.4 & 1.2 & 4.6 \\
\hline Topsoil phosphorus (mg/L) & 9.2 & 16.1 & 16.2 & 4.0 & 8.0 \\
\hline Topsoil potassium $(\mathrm{mg} / \mathrm{L})^{\mathrm{y}}$ & 79 & 303 & 81 & 88 & 82 \\
\hline Planting year & $1993 / 1996$ & 1994 & 1994 & 1994 & 1994 \\
\hline
\end{tabular}

${ }^{\mathrm{z}}$ The DAMS windiness score is a function of elevation, topographic exposure, aspect, funneling effects, and wind zoning of the country (Bell et al. 1995).

${ }^{\mathrm{y}}$ Soil analyses follow Ministry of Agriculture, Fisheries and Food (1986).

to tolerance to soil $\mathrm{pH}$, texture, and risk of drought. Ash (Fraxinus excelsior L.), beech (Fagus sylvatica L.), Corsican pine (Pinus nigra var. maritima [Ait.] Melville), English oak (Quercus robur L.), hybrid larch (Larix $\times$ marschlinsii Coaz), Italian alder (Alnus cordata [Loisel.] Duby), Japanese larch (Larix kaempferi [Lamb.] Carr.), Leyland cypress ( $\times$ Cupressocyparis leylandii [Dallimore and Jackson] Farjon), Norway maple (Acer platanoides L.), silver maple (Acer saccharinum L.), sycamore (Acer pseudoplatanus L.), whitebeam (Sorbus aria [L.] Crantz), white poplar (Populus alba L.), and wild cherry (Prunus avium L.) were used. A selection of broadly similar species was made at Yanley, Beech Farm, Pimbo, and Grunty Fen; but at Shaw Tip, beech, Leyland cypress, and silver maple were chosen for their reported ability to tolerate soil substrates of high $\mathrm{pH}$.

Bare-rooted transplants were used for all experiments, except poplar, which was planted as rooted cuttings, and pine and cypress, which were cell-grown in Japanese paper pots. Trees were planted at $1.5 \mathrm{~m}(5 \mathrm{ft})$ spacing following standard practice for brownfield and urban sites (Moffat and McNeill 1994; Hodge 1995). The Beech Farm site was planted in March 1993 and the four other sites between December 1993 and March 1994. Early tree performance of almost all species was disappointing at
Beech Farm, and excavation revealed severe soil compaction below the topsoil, which prevented root penetration and exploitation (Bending and Moffat 1997). The site was therefore totally cultivated (i.e., the soil was mechanically excavated and loosetipped back into place) to $1 \mathrm{~m}$ (3.3 ft) depth in Fall 1995 before complete replanting of the experimental plots in January 1996. At some other sites, too, one or two species failed in the first 2 years, and the decision was made to replace the species plots with an alternative.

Trees were protected from rabbit browsing using standard forestry fencing at all sites. Deer fencing was erected at those sites where there was obvious deer pressure. However, it became necessary to install such fencing at Yanley in 2002 as a result of significant browsing damage there. Weed growth was controlled using contact and residual herbicides for the first 3 years of the project and thereafter by selective mechanical weeding once or twice per year if required. Weed control stopped when trees had grown to sufficient height to be relatively unaffected by weed competition, at Beech Farm in 2001 and at the other sites in 1999.

Tree height was measured at planting and the condition and survival of trees assessed in July each year using the inner matrix of 16 trees in each plot with visits in September to determine

Table 2. Estimated tree survival probabilities after eight growing seasons (nine for beech at Shaw Tip).

\begin{tabular}{|c|c|c|c|c|c|c|c|c|c|c|}
\hline Species & $\begin{array}{l}\text { Beech Farm } \\
\text { survival }\end{array}$ & SE & $\begin{array}{l}\text { Grunty Fen } \\
\text { survival }\end{array}$ & SE & $\begin{array}{l}\text { Pimbo } \\
\text { survival }\end{array}$ & SE & $\begin{array}{l}\text { Shaw Tip } \\
\text { survival }\end{array}$ & SE & $\begin{array}{l}\text { Yanley } \\
\text { survival }\end{array}$ & SE \\
\hline Ash & 0.86 & 0.068 & 0.14 & 0.068 & 0.88 & 0.065 & 0.98 & 0.024 & 0.66 & 0.093 \\
\hline Beech & & & & & & & 0.81 & 0.076 & & \\
\hline Corsican pine & 0.69 & 0.128 & 0.48 & 0.098 & 0.52 & 0.098 & & & 0.52 & 0.098 \\
\hline English oak & 0.78 & 0.081 & 0.08 & 0.052 & 0.64 & 0.094 & & & 0.63 & 0.095 \\
\hline Hybrid larch & & & & & 0.29 & 0.103 & & & & \\
\hline Italian alder & 0.36 & 0.094 & 0.00 & 0.001 & & & 0.77 & 0.083 & 0.41 & 0.096 \\
\hline Leyland cypress & & & & & & & 0.55 & 0.097 & & \\
\hline Norway maple & 0.77 & 0.083 & & & & & & & & \\
\hline Silver maple & & & & & & & 0.91 & 0.057 & & \\
\hline Sycamore & & & 0.38 & 0.095 & 0.44 & 0.097 & & & 0.41 & 0.096 \\
\hline White poplar & 0.41 & 0.096 & 0.55 & 0.097 & 0.88 & 0.065 & 0.88 & 0.065 & 0.83 & 0.074 \\
\hline Whitebeam & 0.94 & 0.047 & 0.91 & 0.057 & 0.77 & 0.083 & 0.77 & 0.083 & 0.55 & 0.097 \\
\hline Wild cherry & 0.78 & 0.081 & 0.47 & 0.098 & 0.80 & 0.079 & 0.80 & 0.079 & 0.19 & 0.076 \\
\hline
\end{tabular}

$\mathrm{SE}=$ standard error. 


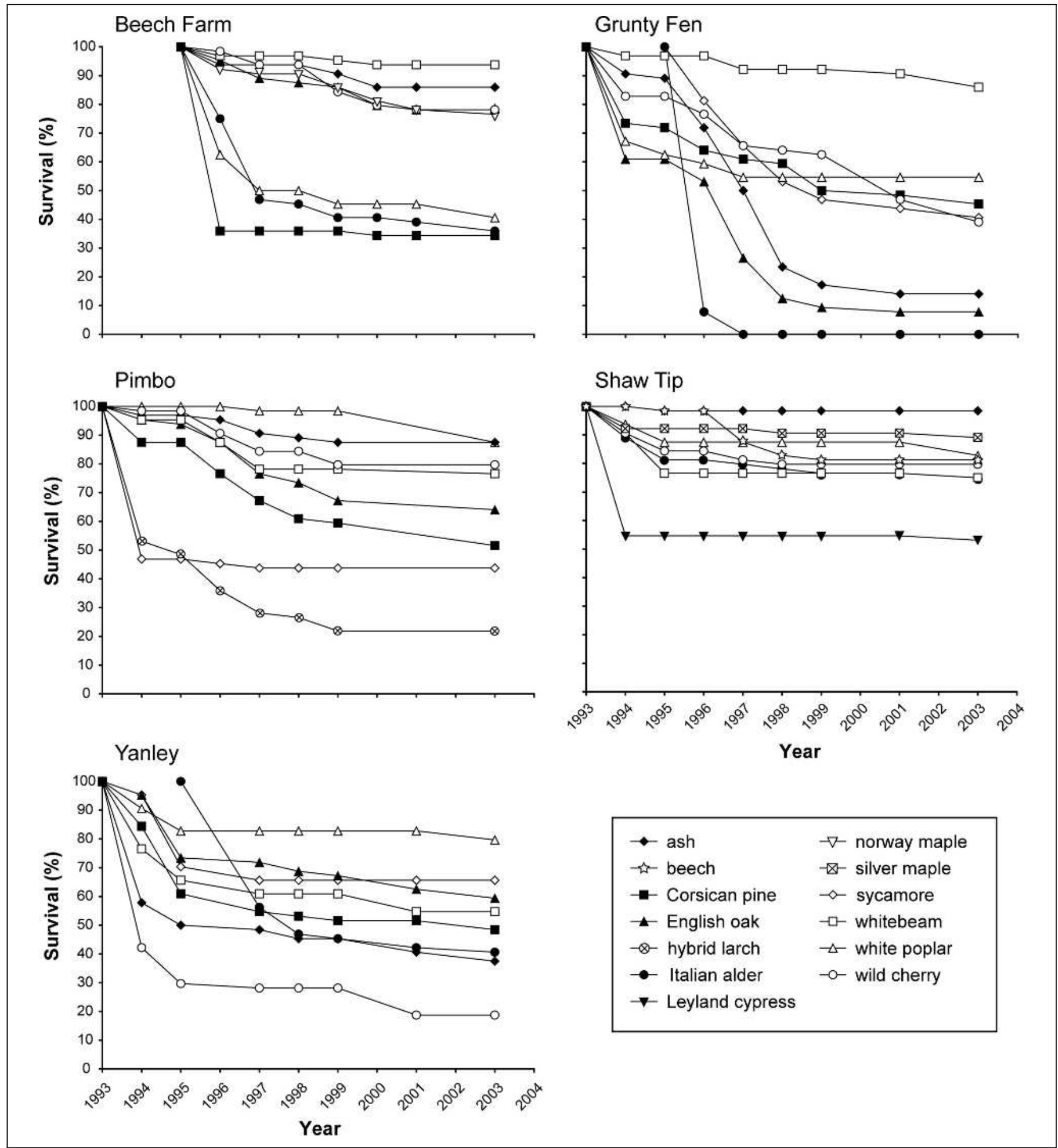

Figure 1. Percentage tree survival at the five experimental sites. Note: The entire Beech Farm site was replanted at the end of 1995, Italian alder replaced Japanese larch and sycamore replaced Norway maple in January 1996 at Grunty Fen, Beech was replanted in January 1995 at Shaw Tip, Italian alder replaced Japanese larch in January 1996 at Yanley.

precise failure numbers. Tree height and growth increment were measured annually in the dormant season (November to March) between 1994 and 1999 and then every 2 years between 2000 and 2003. In the first 2 years of the experiment, all failed trees were replaced with new plants in the winter after a height assessment.

Yield class gives a clearer indication than tree height of how well a species is performing against the potential that it might 
attain at a given age assuming standard forestry practice (Edwards and Christie 1981). It is equivalent to site index as used in the United States and elsewhere. General yield class is based on the mean height of the 100 tallest trees in a stand (Rollinson 1991), but in this study, it was calculated for each species based on mean height data resulting from the inadequate number of measured trees in each plot. Because trees at Beech Farm were younger than 10 years, no yield class data were derived for this site.

Foliar samples were collected from each site in August (deciduous species) and November (evergreens) in 1998 and 2001 following standard procedures (Taylor 1991); a bulked sample was obtained from representative leaves or needles from five trees per plot. The samples were analyzed at the Forest Research Chemical Laboratories in Farnham, Surrey, U.K. Individual samples were ground and then digested with a mixture of sulphuric acid and hydrogen peroxide. Nitrogen and phosphorus concentrations were measured by colorimetry and base cations by plasma emission spectroscopy according to standard operating procedures established in the laboratory. Quality control was ensured by the inclusion of two certified reference materials (NCS DC73350 and DC3351 from the China National Analysis Center for Iron and Steel) in each batch of samples. The experimental plots were fertilized with nitrogen (as urea) at $150 \mathrm{~kg}$ N/ha (134 lb/acre) in April 1999 and April 2002. Fertilizer was applied in $1 \mathrm{~m}(3.3 \mathrm{ft})$ spots around each tree.

Because of the replacement of a few species at some sites in the first 2 years after the experiments began, an index of comparative survival was based on the number of live trees of each species at each site after eight growing seasons. This was analyzed statistically using a binomial generalized linear model with logit link and a binomial denominator of 16 . The exception was for beech at Shaw Tip where survival after 9 years was used because no observations were made at 8 years. Replacement trees were not included in the analysis. Tree heights at Year 8 were log-transformed to stabilize the variance, and the logtransformed heights were analyzed using a general linear model. Analysis was based on the trees planted at the beginning of the experiments, and replacement trees were not included. For both survival and height comparison, there were no significant differences between experiment blocks and so site mean tree species values were used in subsequent analysis and evaluation. All statistical analyses were undertaken using Genstat version 8.1 (GenStat 2005).

\section{RESULTS AND DISCUSSION}

\section{Survival}

Table 2 shows estimated tree survival probabilities and their standard errors after eight (nine) growing seasons, and Figure 1 shows the change in survival rate since planting based on the original stock. The species by site interaction was significant $(P<0.001)$. The calendar year was not significant, indicating that data were comparable despite some species being planted a year or two apart from the others. Considering the range of species, overall tree survival performance was best at Shaw Tip and worst at Grunty Fen. Most sites showed an initial decline in the total number of trees of each species that tended to stabilize with time. Compared with the traditional guidance of approximately $80 \%$ for acceptable stocking density of new closely spaced plantations on greenfield sites (Hart 1991), survival has been broadly acceptable for woodland establishment at most sites and for most tree species. This suggests that site preparation, tree planting operations, and silvicultural care have been suitable for the purpose of establishing trees on the experimental plots.

There was no indication of group dieback resulting from landfill gas within the soil cover at any site, and the early decline in tree numbers at some sites is likely to reflect soil drainage conditions or quality of planting stock rather than possible effects of landfill gas or heat (Moffat and Houston 1991). Differences in survival rates between species over the longer term may be explained by the general tolerance of the different species to specific site conditions. Hence, at Shaw Tip, the survival rate stabilized within 2 years of planting, whereas at Pimbo, some species showed a continued decline in numbers, which may be related to their inability to tolerate site conditions. The poor survival at Grunty Fen is probably the result of the small available water capacity of the clayey planting medium (estimated at $13 \%$ by volume [Hodgson 1976]) combined with the high soil moisture deficit experienced at the site, which is situated in the driest part of the country. The mean maximum potential soil moisture deficit (PSMD) between 1994 and 2004 at Broom's Barn $30 \mathrm{~km}(18 \mathrm{mi})$ east southeast of Grunty Fen was almost $250 \mathrm{~mm}$ (10 in), and maximum PSMD ranged between 280 and $430 \mathrm{~mm}$ (11.2 and 17.2 in) in the first 5 years.

Species that showed consistently good survival performance across most of the sites included ash, whitebeam, white poplar, and wild cherry (Table 2). All species at Shaw Tip, with the

Table 3. Predicted means of log tree height $(\mathrm{m})$ after eight growing seasons (nine for beech at Shaw Tip).

\begin{tabular}{|c|c|c|c|c|c|c|c|c|c|c|}
\hline Species & $\begin{array}{l}\text { Beech Farm } \\
\text { mean }\end{array}$ & SE & $\begin{array}{l}\text { Grunty Fen } \\
\text { mean }\end{array}$ & SE & $\begin{array}{l}\text { Pimbo } \\
\text { mean }\end{array}$ & SE & $\begin{array}{l}\text { Shaw Tip } \\
\text { mean }\end{array}$ & SE & $\begin{array}{l}\text { Yanley } \\
\text { mean }\end{array}$ & SE \\
\hline Ash & 5.55 & 0.171 & 4.1 & 0.197 & 5.84 & 0.171 & 6.22 & 0.171 & 5.66 & 0.171 \\
\hline Beech & & & & & & & 5.90 & 0.171 & & \\
\hline Corsican pine & 5.81 & 0.241 & 4.65 & 0.171 & 5.34 & 0.171 & & & 5.23 & 0.171 \\
\hline English oak & 5.35 & 0.171 & 4.71 & 0.341 & 5.43 & 0.171 & & & 5.00 & 0.171 \\
\hline Hybrid larch & & & & & 5.83 & 0.197 & & & & \\
\hline Italian alder & 6.37 & 0.171 & & & & & 6.54 & 0.171 & 6.32 & 0.171 \\
\hline Leyland cypress & & & & & & & 6.35 & 0.171 & & \\
\hline Norway maple & 5.74 & 0.171 & & & & & & & & \\
\hline Silver maple & & & & & & & 6.38 & 0.171 & & \\
\hline Sycamore & & & 4.60 & 0.171 & 5.53 & 0.171 & & & 4.61 & 0.171 \\
\hline White poplar & 6.25 & 0.171 & 5.89 & 0.171 & 6.44 & 0.171 & 6.55 & 0.171 & 6.48 & 0.171 \\
\hline Whitebeam & 5.51 & 0.171 & 5.24 & 0.171 & 5.43 & 0.171 & 5.72 & 0.171 & 5.33 & 0.171 \\
\hline Wild cherry & 5.94 & 0.171 & 5.37 & 0.171 & 6.00 & 0.171 & 5.94 & 0.171 & 4.56 & 0.171 \\
\hline
\end{tabular}

$\mathrm{SE}=$ standard error. 
exception of Leyland cypress, maintained survival rates in excess of $70 \%$ of the original numbers planted. Ash and wild cherry demonstrated good survival performance under the relatively wet conditions at Pimbo, whereas English oak and ash at the Yanley and Beech Farm sites and Norway maple at Beech Farm also retained a high survival rate. Apart from whitebeam, most species at Grunty Fen declined over the 10-year period and only white poplar showed signs of stabilizing at a survival rate of approximately $55 \%$ by 2003 . Species that performed very poorly at the low rainfall Grunty Fen site included Japanese larch, Italian alder, English oak, and ash. The poor survival of original trees of Italian alder and wild cherry at Yanley and white poplar, Italian alder, and Corsican pine at Beech Farm was caused by deer browsing.

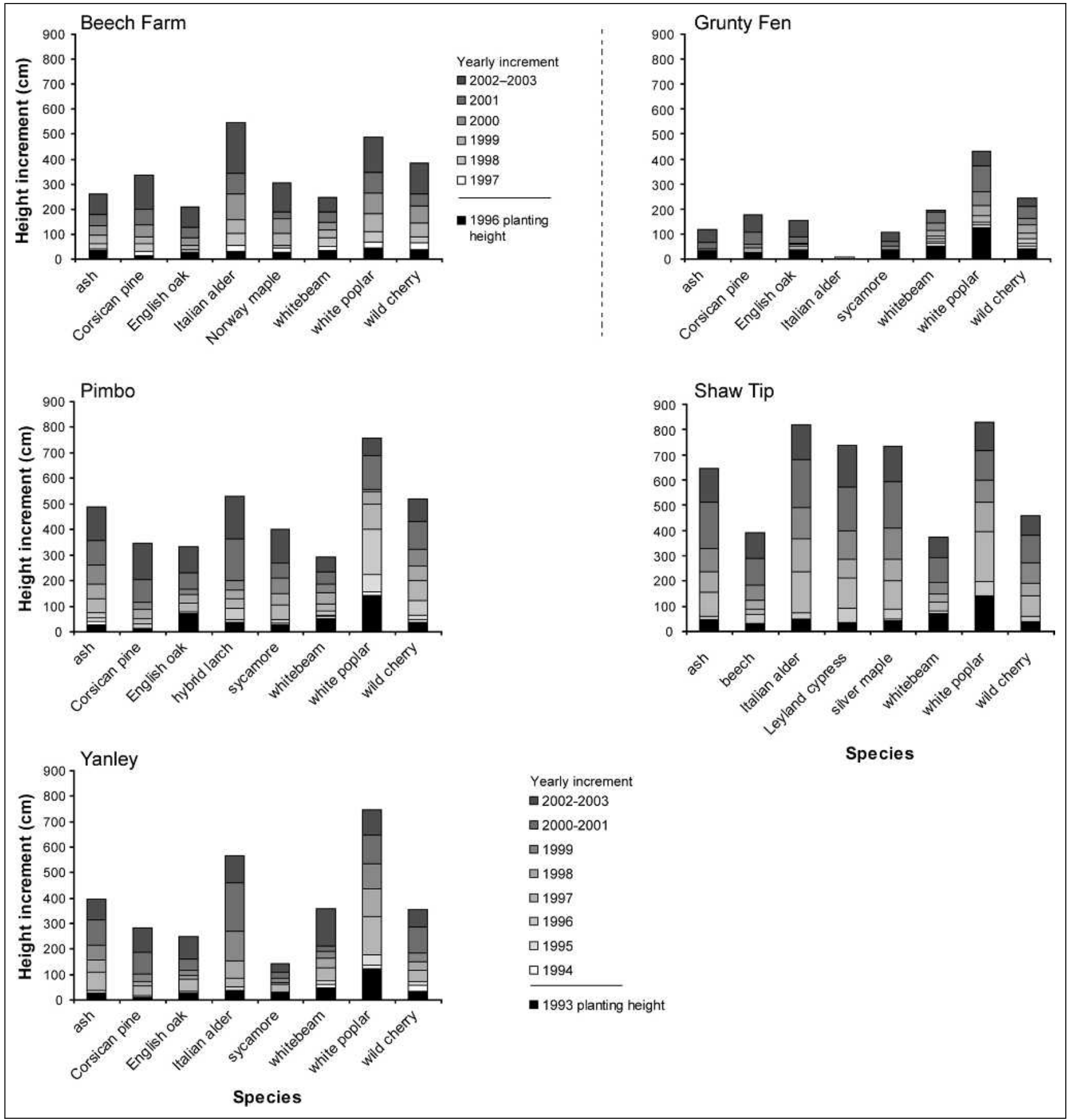

Figure 2. Mean annual tree height increments at the five landfill sites since planting. Note: The legend for Beech Farm is different from the other four sites. 


\section{Growth}

Tree growth was evaluated by means of annual measurements of height from 1994 to 1999 and on a 2-year basis from 2000 onward, except at Beech Farm where annual observations were continued until 2001 as a result of replanting of the experiment. Table 3 contains the predicted means of $\log$ tree height at age 8 years (9 years). The species by site interaction was again significant $(P<0.001)$ and, similar to the survival analysis, the year of planting was not. Figure 2 shows the mean annual increment and height for each of the species at each site. It shows that Shaw Tip produced the fastest height growth rates for most species and that the slowest tree growth occurred at Grunty Fen. Across all sites, height growth rates were greatest in the poplar, alder, cherry, whitebeam, and ash species. Species with slow absolute growth rates included beech, sycamore, and oak, although care must be exercised in making comparisons among species with different growth habits.

Growth increments did not show steady annual increases and the performance of individual species planted at different sites was also markedly variable. This probably reflects different climatic or site conditions such as soil moisture or nutrient status in different years. However, annual increments of most species at Grunty Fen appeared to be suppressed compared with the other sites, especially between 1994 and 1999, and tree growth rate has showed little tendency to accelerate in more recent years at this site.

Most species reached their maximum annual increment in 2000 to 2001 or in 2002 to 2003 (Table 4), which may reflect, in part, the fertilizer applications in 1999 and 2002. Annual rainfall data from three meteorological stations within reasonable proximity to Yanley (Long Ashton), Shaw Tip (Oxford), and Pimbo (Bradford) indicate that 1995 to 1996 were relatively dry years, which may help to explain the small increments in annual growth rate during this period. It is also possible that tree growth responded to the upturn in annual rainfall between 1997 and 2000. Summer drought in 1995 was very pronounced at all sites, which probably explains why such poor height increments were experienced in the subsequent growth period.

\section{Nutrition}

Taylor (1991) gives foliar nitrogen $(\mathrm{N})$, phosphorus (P), and potassium $(\mathrm{K})$ concentrations that are regarded as representing deficient and optimal conditions for the more common species in
British forestry. For the remaining species, information from Auchmoody and Smith (1977), Callan and Westcott (1996), and Ystaas and Frøynes (1997) was used to estimate deficient and optimal values. The appropriate values for optimum and deficient $\mathrm{N}, \mathrm{P}$, and $\mathrm{K}$ status are presented in Table 5 together with an assessment of the status of each of the tree species at each of the five sites. The results demonstrate that $\mathrm{N}$ deficiency was widespread with most species demonstrating severe deficiency at two or more sites. Only white poplar and Italian alder demonstrated optimal $\mathrm{N}$ status at some sites. These results generally agree with the growth data discussed previously and may explain the reduced growth rate in some species in 2000 to 2001. Italian alder might be expected to show less of a $\mathrm{N}$ deficiency than other species because of its $\mathrm{N}$-fixing capability when infected with the actinomycete Frankia. However, it is possible that at some sites, trees were poorly nodulated, impairing their ability to fix $\mathrm{N}$. When reapplication of $\mathrm{N}$ fertilizer was made in Spring 2002, the maximum annual increment in 2002 to 2003 was identified in some species (Table 4), which might be attributed to this addition.

Phosphorus and K were generally optimal in whitebeam, sycamore, poplar, cherry, and ash but showed some deficiency in other species. Corsican pine was deficient in $\mathrm{P}$ and $\mathrm{K}$ at most sites. Oak and beech also exhibited slight or moderate deficiencies in $\mathrm{K}$. The foliar data confirm that $\mathrm{K}$ supply is generally not a problem for woodland establishment on brownfield land (Moffat and McNeill 1994).

In 1998, of the 37 combinations of species and site investigated, only three, alder at Shaw Tip and poplar at Pimbo and Beech Farm, were considered to have optimal nutrient supply (Kennedy and Moffat 1999). In 2001, only four had optimal supply of all three nutrients despite a $\mathrm{N}$ application in Spring 1999; species include poplar at Pimbo, Shaw Tip, and Yanley and Italian alder at Yanley. The deficiencies identified in the 2001 foliar analysis demonstrate the lack of impact longevity of the applied $\mathrm{N}$ fertilizer. It is possible that considerable leaching of $\mathrm{N}$ occurred in the soil materials used, most of which contained little organic matter. Reclamation using these materials in 1993 to 1994 predated guidance on soil-forming materials (Bending et al. 1999), which strongly advocated the use of organic wastes to build up fertility and nutrient-holding capacity of the substrates. Experience from this study would appear to confirm the applicability of this guidance, because supplementary fertilizer application was required only 3 years after the first application. Re-

Table 4. The year species achieved their maximum annual height increment during the 10 -year monitoring period (1993 to 2003).

\begin{tabular}{|c|c|c|c|c|c|}
\hline & Beech Farm & Grunty Fen & Pimbo & Shaw Tip & Yanley \\
\hline Ash & 2001 & 2002-2003 & 1999 & 1997 & 1997 \\
\hline Beech & - & - & - & 1999 & - \\
\hline Corsican pine & 2002-2003 & 2002-2003 & 2002-2003 & - & 2002-2003 \\
\hline English oak & 2001 & 2002-2003 & $2002-2003$ & - & 1997 \\
\hline Hybrid larch & - & - & $2002-2003$ & - & - \\
\hline Italian alder & 2000 & - & - & 1997 & 1999 \\
\hline Leyland cypress & - & - & - & 1997 & - \\
\hline Silver maple & 2002-2003 & - & - & 1999 & - \\
\hline Sycamore & - & 2002-2003 & 2002-2003 & - & 1997 \\
\hline Whitebeam & 2001 & 1999 & 1998 & 2000-2001 & 2002-2003 \\
\hline White poplar & 2001 & 1999 & 1996 & 1997 & 1997 \\
\hline Wild cherry & 2000 & 1998 & 1997 & 1997 & 2000-2001 \\
\hline
\end{tabular}


Table 5. Foliar nutrient status at the experimental sites in 1998 and $2001 .^{z}$

\begin{tabular}{|c|c|c|c|c|c|c|c|c|c|c|c|c|}
\hline \multicolumn{13}{|c|}{ Nitrogen status } \\
\hline Species & $\begin{array}{l}\text { Beech } \\
\text { Farm } \\
1998\end{array}$ & 2001 & $\begin{array}{l}\text { Grunty } \\
\text { Fen } \\
1998\end{array}$ & 2001 & $\begin{array}{l}\text { Pimbo } \\
1998\end{array}$ & 2001 & $\begin{array}{l}\text { Shaw } \\
\text { Tip } \\
1998\end{array}$ & 2001 & $\begin{array}{l}\text { Yanley } \\
1998\end{array}$ & 2001 & $\begin{array}{l}\text { Deficient } \\
\text { (\% dry wt) }\end{array}$ & $\begin{array}{l}\text { Optimum } \\
\text { (\% dry wt) }\end{array}$ \\
\hline Ash & -- & -- & -- & -- & -- & -- & -- & - & - & -- & $<2.0$ & $>2.3$ \\
\hline Beech & NA & NA & NA & NA & NA & NA & -- & -- & NA & NA & $<2.0$ & $>2.3$ \\
\hline Corsican pine & - & -- & -- & -- & -- & -- & NA & NA & - & - & $<1.2$ & $>1.5$ \\
\hline English oak & -- & -- & -- & -- & - & - & NA & NA & -- & -- & $<2.0$ & $>2.3$ \\
\hline Hybrid larch & NA & NA & NA & NA & -- & - & NA & NA & NA & NA & $<1.8$ & $>2.5$ \\
\hline Italian alder & No data & + & No data & -- & NA & NA & + & - & -- & + & $<2.5$ & $>2.8$ \\
\hline Leyland cypress & NA & NA & NA & NA & NA & NA & -- & -- & NA & NA & $<1.2$ & $>2.3$ \\
\hline Sycamore & NA & NA & No data & -- & -- & -- & NA & NA & -- & -- & $<2.0$ & $>2.3$ \\
\hline Silver maple & - & -- & NA & NA & NA & NA & -- & -- & NA & NA & $<2.0$ & $>2.3$ \\
\hline Whitebeam & -- & -- & -- & -- & -- & -- & -- & -- & -- & -- & $<2.0$ & $>2.3$ \\
\hline White poplar & + & - & - & -- & + & + & - & + & - & + & $<2.0$ & $>2.3$ \\
\hline Wild cherry & - & -- & - & -- & - & -- & -- & -- & - & -- & $<2.0$ & $>2.3$ \\
\hline \multicolumn{13}{|c|}{ Phosphorus status } \\
\hline Species & $\begin{array}{l}\text { Beech } \\
\text { Farm } \\
1998\end{array}$ & 2001 & $\begin{array}{l}\text { Grunty } \\
\text { Fen } \\
1998 \\
\end{array}$ & 2001 & $\begin{array}{l}\text { Pimbo } \\
1998\end{array}$ & 2001 & $\begin{array}{l}\text { Shaw } \\
\text { Tip } \\
1998\end{array}$ & 2001 & $\begin{array}{l}\text { Yanley } \\
1998\end{array}$ & 2001 & $\begin{array}{l}\text { Deficient } \\
(\% \text { dry wt })\end{array}$ & $\begin{array}{l}\text { Optimum } \\
\text { (\% dry wt) }\end{array}$ \\
\hline Ash & + & - & -- & + & + & + & + & + & + & + & $<0.19$ & $>0.22$ \\
\hline Beech & NA & NA & NA & NA & NA & NA & - & -- & NA & NA & $<0.14$ & $>0.16$ \\
\hline Corsican pine & - & - & -- & -- & - & - & NA & NA & -- & - & $<0.12$ & $>0.16$ \\
\hline English oak & + & + & -- & + & + & + & NA & NA & -- & + & $<0.14$ & $>0.16$ \\
\hline Hybrid larch & NA & NA & NA & NA & + & + & NA & NA & NA & NA & $<0.18$ & $>0.25$ \\
\hline Italian alder & No data & -- & No data & + & NA & NA & - & -- & -- & + & $<0.16$ & $>0.18$ \\
\hline Leyland cypress & NA & NA & NA & NA & NA & NA & + & + & NA & NA & $<0.12$ & $>0.16$ \\
\hline Sycamore & NA & NA & No data & + & + & + & NA & NA & + & + & $<0.17$ & $>0.20$ \\
\hline Silver maple & + & + & NA & NA & NA & NA & - & - & NA & NA & $<0.19$ & $>0.22$ \\
\hline Whitebeam & + & + & + & + & + & + & + & + & + & + & $<0.17$ & $>0.20$ \\
\hline White poplar & + & + & + & - & + & + & + & + & + & + & $<0.17$ & $>0.20$ \\
\hline Wild cherry & + & + & + & + & + & + & + & + & + & + & $<0.17$ & $>0.20$ \\
\hline \multicolumn{13}{|c|}{ Potassium status } \\
\hline Species & $\begin{array}{l}\text { Beech } \\
\text { Farm } \\
1998 \\
\end{array}$ & 2001 & $\begin{array}{l}\text { Grunty } \\
\text { Fen } \\
1998 \\
\end{array}$ & 2001 & $\begin{array}{l}\text { Pimbo } \\
1998 \\
\end{array}$ & 2001 & $\begin{array}{l}\text { Shaw } \\
\text { Tip } \\
1998\end{array}$ & 2001 & $\begin{array}{l}\text { Yanley } \\
1998\end{array}$ & 2001 & $\begin{array}{l}\text { Deficient } \\
(\% \text { dry wt })\end{array}$ & $\begin{array}{l}\text { Optimum } \\
(\% \text { dry wt })\end{array}$ \\
\hline Ash & + & + & + & + & + & + & + & + & + & + & $<0.7$ & $>0.9$ \\
\hline Beech & NA & NA & NA & NA & NA & NA & -- & -- & NA & NA & $<0.7$ & $>0.9$ \\
\hline Corsican pine & - & + & - & - & - & - & NA & NA & - & - & $<0.3$ & $>0.5$ \\
\hline English oak & + & - & - & + & - & - & NA & NA & + & + & $<0.7$ & $>0.9$ \\
\hline Hybrid larch & NA & NA & NA & NA & + & + & NA & NA & NA & NA & $<0.5$ & $>0.8$ \\
\hline Italian alder & No data & -- & No data & + & NA & NA & + & - & + & + & $<0.7$ & $>0.9$ \\
\hline Leyland cypress & NA & NA & NA & NA & NA & NA & + & + & NA & NA & $<0.3$ & $>0.5$ \\
\hline Sycamore & NA & NA & No data & + & - & + & NA & NA & + & + & $<0.7$ & $>0.9$ \\
\hline Silver maple & + & + & NA & NA & NA & NA & + & + & NA & NA & $<0.7$ & $>0.9$ \\
\hline Whitebeam & + & + & + & + & + & + & + & + & + & + & $<0.7$ & $>0.9$ \\
\hline White poplar & + & + & + & - & + & + & + & + & + & + & $<0.7$ & $>0.9$ \\
\hline Wild cherry & + & + & + & + & + & + & + & + & + & + & $<0.7$ & $>0.9$ \\
\hline
\end{tabular}

${ }^{\mathrm{z}}$ Analyses based on bulk sample from five trees in each plot. Definition of optimum, deficient, and very deficient status derived from Taylor (1991), Auchmoody and Smith (1977), Callan and Westcott (1996), and Ystaas and Frøynes (1997).

$--=$ deficient $;-=$ slightly deficient; $+=$ optimum.

$\mathrm{NA}=$ not applicable.

liance on the regular and continued application of mineral fertilizer to maintain stand growth and condition does not support sustainability principles and is a drain on maintenance budgets. Instead, sites should be prepared with amendments of organic waste materials if soil-forming materials are used for reclamation purposes.

\section{Comparison with Trees on Other Landfill and Greenfield Sites}

Rawlinson et al. (2004) found that of 21 species tested experimentally, native and broadleaved species were most successful after 3 years. Handel and McLaughlin (2006) also suggested that native species can flourish on properly restored landfills. In con- 
trast, Dobson and Moffat (1993) reviewed the results of tree growth on 19 restored landfill sites and found considerable variation in the performance of different species, both native and nonnative, coniferous and broadleaved. This study has also found that nonnatives performed well on some sites but not others; there appears to be no universal truth in this respect. Instead, simple analysis of the performance of individual species over a 10-year period suggests that soil and site characteristics such as climate are very important. Like Rawlinson et al. (2004), we found conifers to perform badly, but this is probably the result of the alkaline nature of the soil substrates at almost all the experimental sites.

Table 6 presents the yield class for selected species at Year 10 compared with regional averages derived from data from forests and woodlands on undisturbed land. The results confirm the relatively poor performance of trees at Grunty Fen and the impressive growth at Shaw Tip. The conifers naturally demonstrate a larger yield class than the broadleaves, and growth was better than average at Shaw Tip and Pimbo. Of the broadleaves, oak showed consistent growth closest to average expectations, although with only one or two exceptions (e.g., ash at Grunty Fen and sycamore at Yanley), growth of broadleaved species was reasonable given the comparatively hostile conditions at most sites.

\section{Implications for Woodland Establishment on Landfill Sites}

Taken together, the 10 years of monitoring field experiments on modern landfill sites suggest that it is possible to establish woodland composed of tree species that grow reasonably well compared with equivalents established on greenfield sites. From an engineering standpoint, the results reinforce the need for uncompacted, rootable soil or soil-forming material, preferably placed by loose tipping or "complete cultivation." The widespread $\mathrm{N}$ deficiency detected during the monitoring program was predictable given the relatively infertile materials used in restoration at most sites (Table 1). However, there was no opportunity to use organic waste materials such as sewage sludge or composts as an overall treatment to the sites. The inability of artificial mineral fertilizers to redress permanent nutrient deficiency in the field experiments underlines the need for alternatives such as organic amendments, which are often a more effective approach to restore land amendment (Bending et al. 1999; Moffat 2006).

Proper attention to provision of a suitable thickness of soil or soil-forming material, prevention of compaction, and site fertility can maximize the likelihood of good tree performance. However, there was some evidence from the field experimentation program that regional rainfall, or lack of it, was also important. For some parts of the country, notably the drier south and east, meticulous weed control is increasingly necessary, but even if undertaken according to good forestry practice, there remains a risk to tree survival and performance on those sites where plantavailable water may be limited, for example at Grunty Fen where low rainfall combined with a clayey substrate of low available water capacity. The potential influence of climate change has been appreciated in recent guidance on suitable soil provision for landfill and other restored brownfield sites (Moffat 1995), but further work is needed to refine this in the light of governmentpredicted climate change scenarios (Hulme et al. 2002).

Considered species selection is an obvious way to maximize the likelihood of a successful woodland, and the field experimental program has demonstrated that some tree species tested are more robust and/or provide a low risk of failure. These have been discussed in this article. Other tree species, especially Leyland cypress, Japanese larch, and Norway maple, performed very poorly during the experiment and should be chosen with care in future schemes on similar sites. The basic maxim is to match species to site conditions as much as possible and to be conservative in the expectations for the new woodland, e.g., not to expect tree species typical of natural woodland to thrive on unamended soil-forming materials, but to choose so-called pioneer species like poplars and alders, which are comparatively tolerant of infertility and exposure.

However, climate change makes it more difficult to be certain about choice of species because the climate in future years is likely to be significantly different than today, especially in the south and east of the British Isles (Broadmeadow et al. 2004). In these regions, notably drought-tolerant species should be chosen. Some species such as white poplar may perform well as a response to climate change (Cannell et al. 1989), but others such as cherry may fare less well than today. It may also be necessary to consider species not tested in these experiments such as walnut

Table 6. Measured and regional average general yield classes ( $\mathrm{m}^{3} / \mathrm{ha} /$ year) at Year 10 for all sites except Beech Farm. ${ }^{\mathrm{z}}$

\begin{tabular}{|c|c|c|c|c|c|c|c|c|}
\hline \multirow[b]{2}{*}{ Species } & \multicolumn{2}{|c|}{ Grunty Fen } & \multicolumn{2}{|c|}{ Pimbo } & \multicolumn{2}{|c|}{ Shaw Tip } & \multicolumn{2}{|c|}{ Yanley } \\
\hline & Measured & $\begin{array}{l}\text { Regional } \\
\text { average }\end{array}$ & Measured & $\begin{array}{l}\text { Regional } \\
\text { average }\end{array}$ & Measured & $\begin{array}{l}\text { Regional } \\
\text { average }\end{array}$ & Measured & $\begin{array}{l}\text { Regional } \\
\text { average }\end{array}$ \\
\hline Ash & 2 & 5 & 8 & NA & 10 & 5 & 6 & 5 \\
\hline Beech & & & & & 10 & 7 & & \\
\hline Corsican pine & 6 & 15 & 16 & 14 & & & 12 & 16 \\
\hline English oak & 4 & 5 & 8 & 7 & & & 6 & 5 \\
\hline Hybrid larch & & & 12 & 11 & & & & \\
\hline Italian alder & NA & NA & & 12 & 6 & NA & NA & \\
\hline Leyland cypress & & & & & 24 & 15 & & \\
\hline Silver maple & & & & & 10 & 7 & & \\
\hline Sycamore & NA & & 4 & 6 & & & 2 & 5 \\
\hline Whitebeam & 4 & NA & 6 & NA & 8 & NA & 8 & NA \\
\hline White poplar & 4 & NA & 4 & 6 & 6 & 6 & 4 & 6 \\
\hline Wild cherry & 4 & 4 & 8 & NA & 8 & 10 & 6 & 10 \\
\hline
\end{tabular}

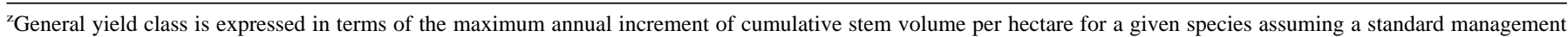
regime.

$\mathrm{NA}=$ yield class curves not available (trees less than 10 years old) for these species. 
(Juglans nigra L.), holm oak (Quercus ilex L.), Eucalyptus spp., and Nothofagus spp. Such species are, of course, nonnative to the British Isles.

Of the species tested and found to be relatively successful, some caution should be exercised on mineral-capped landfills if selecting poplar and alder species. Bending and Moffat (1997) found that poplar roots were effective in penetrating clay compacted to levels required of mineral caps (greater than 1.8 $\left.\mathrm{g} / \mathrm{cm} ; 15.0 \mathrm{lb}_{\text {gallon }}{ }^{-1}\right)$, and Hutchings et al. $(2001,2006)$ obtained similar results for alder species on a containment landfill in Hertfordshire. These species are relatively tolerant of soil anaerobism and might be expected to pose a risk of root penetration on landfills where the cap suffers from weakness in its fabric and/or is unprotected by an artificial capping layer. The likelihood of downward root growth toward and potentially into the landfill cap will be exacerbated by climate change in southern and eastern England. It is therefore important to consider the water demands of a mature woodland established on soil materials over a mineral cap at the time of soil placement to provide sufficient thickness to supply plant-available water during future summer months. This may require a soil thickness in excess of $1.5 \mathrm{~m}(5 \mathrm{ft})$ in eastern parts of England, depending on soil texture and stoniness (Moffat 1995).

\section{CONCLUSIONS}

The trees on the experimental landfill sites are relatively young (10 years old), and the interaction between tree rooting and the landfill cap environment is expected to become more complex as the trees grow and mature and begin to encounter further limitations to growth. The five experiments are thus a valuable resource as a means of monitoring species tolerance and performance on landfill sites over time and as a potential source of material on which to study root/landfill cap interactions in the future. More reliable information on both these issues will become available as the monitoring plots mature.

Acknowledgments. We are grateful to the Office of the Deputy Prime Minister (now Department of Communities and Local Government) for funding the research reported here, in particular Dr. Tom Simpson for his support. We thank the various landfill owners for supporting the experimental work on their land. Forest Research colleagues in the Technical Support Unit and Nigel Bending gathered most of the field data. Ernest Ward was responsible for chemical analysis of the foliar samples. Lesley Halsall kindly provided the regional yield class data and Gill Tuck (Rothamsted Research) provided soil moisture deficit data from Broom's Barn.

\section{LITERATURE CITED}

Auchmoody, L.R., and H.C. Smith. 1977. Response of yellow-poplar and red oak to fertilization in West Virginia. Soil Science Society of America Journal 41:803-807.

Bell, P.D., C.P. Quine, and J.A. Wright. 1995. The use of digital terrain models to calculate windiness scores for the windthrow hazard classification. Scottish Forestry 49:217-225.

Bending, N.A.D., S.G. McRae, and A.J. Moffat. 1999. The Use of Soil-Forming Materials in Land Reclamation. The Stationery Office, London.

Bending, N.A.D., and A.J. Moffat. 1997. Tree Establishment on Landfill Sites. Research and Updated Guidance. Forestry Commission, Edinburgh.

British Standards Institution. 1994. BS3882: Specification for Topsoil. BSI, London.

Broadmeadow, M., D. Ray, L. Sing, and L. Poulsom. 2004. Climate change and British woodland: What does the future hold? In Forest Research Annual Report and Accounts 2002-2003. pp. 70-83.

California Integrated Waste Management Board. 1999. A Guide to the Revegetation and Environmental Restoration of Closed Landfills. www.ciwmb.ca.gov/LEACentral/Closure/Revegetate/ (accessed 5/2/ 2008).

Callan, N.W., and M.P. Westcott. 1996. Drip irrigation for application of potassium to tart cherry. Journal of Plant Nutrition 19:163-172.

Cannell, M.G.R., J. Grace, and A. Booth. 1989. Possible impacts of climatic warming on trees and forests in the UK: A review. Forestry 62:337-364.

Department of the Environment. 1986. Landfilling Wastes. Waste Management Paper No. 26. HMSO, London.

1996. The Reclamation of Mineral Workings. Minerals Planning Guidance Note 7. The Stationery Office, London.

Dobson, M.C., and A.J. Moffat. 1993. The Potential for Woodland Establishment on Landfill Sites. HMSO, London.

Edwards, P.N., and J.M. Christie. 1981. Yield Models for Forest Management. Forestry Commission Booklet 48. HMSO, London.

Environmental Protection Agency. 1999. Landfill Manuals. Landfill Restoration and Aftercare. Environmental Protection Agency, Wexford.

GenStat. 2005. The Guide to GenStat Release 8.1 Part 2: Statistics. In: Payne, R.W. (Ed.). Lawes Agricultural Trust (Rothamsted Experimental Station). VSN International, Oxford.

Handel, S., and J. McLaughlin. 2006. Reclamation Strategy for Capped Landfill Aims Toward Woodland Restoration. US EPA Technology Innovation Program Technology News and Trends No. 26. http:// cluin.org/products/newsltrs/tnandt/view.cfm?issue $=1006 . \mathrm{cfm} \# 4$ (accessed 5/2/2008).

Hart, C. 1991. Practical Forestry for the Agent and Surveyor. Alan Sutton, Stroud.

Hodge, S.J. 1995. Creating and Managing Woodlands Around Towns. Forestry Commission Handbook 11. HMSO, London.

Hodgson, J.M. 1976. Soil Survey Field Handbook. Soil Survey of England and Wales Technical Monograph No. 5. Harpenden.

Hulme, M., G.J. Jenkins, X. Lu, J.R. Turnpenny, T.D. Mitchell, R.G. Jones, J. Lowe, J.M. Murphy, D. Hassell, P. Boorman, R. McDonald, and S. Hill. 2002. Climate Change Scenarios for the United Kingdom: The UKCIP02 Scientific Report. Tyndall Centre for Climate Change Research, School of Environmental Sciences, University of East Anglia, Norwich. 120 pp.

Hutchings, T.R., A.J. Moffat, and R.A. Kemp. 2001. Effects of rooting and tree growth of selected woodland species on cap integrity in a mineral capped landfill site. Waste Management \& Research 19: 194-200.

Hutchings, T.R., D. Sinnett, A.J. Peace, and A.J. Moffat. 2006. The effect of woodland growth on a containment landfill site in Hertfordshire, UK. Urban Forestry and Urban Greening 5:169-176.

Kennedy, F., and A. Moffat. 1999. Tree species selection for restored landfills. Waste Planning 33:7-8.

Ministry of Agriculture, Fisheries and Food 1986. The Analysis of Agricultural Materials. MAFF Reference Book 427. HMSO, London.

Moffat, A.J. 1995. Minimum soil depths for the establishment of woodland on disturbed ground. Arboricultural Journal 19:19-27.

. 2006. The Use of Sewage Sludges and Composts in Forestry. Forestry Commission Information Note 79, Forestry Commission, Edinburgh.

Moffat, A.J., and T.J. Houston. 1991. Tree establishment and growth at Pitsea landfill site, Essex, UK. Waste Management \& Research 9: $35-46$.

Moffat, A.J., and J.D. McNeill. 1994. Reclaiming Disturbed Land for Forestry. Forestry Commission Bulletin 110. HMSO, London.

Office of Superfund Remediation and Technology Innovation. 2006. Revegetating Landfills and Waste Containment Areas Fact Sheet (EPA 542-F-06-001). US EPA. www.epa.gov/tio/download/remed/ revegetating_fact_sheet.pdf (accessed 5/2/2008). 
Pearce, S.C. 1976. Field Experimentation With Fruit Trees and Other Perennial Plants. Commonwealth Agricultural Bureaux, Slough.

Rawlinson, H., N. Dickinson, P. Nolan, and P. Putwain. 2004. Woodland establishment on closed old-style landfill sites in N.W. England. Forest Ecology and Management 202:265-280.

Rollinson, T.J.D. 1991. Management for timber production, pp. 147-161. In: Hibberd, B.G. (Ed.). Forestry Practice. Forestry Commission Handbook 6. HMSO, London.

Taylor, C.M.A. 1991. Forest Fertilisation in Britain. Forestry Commission Bulletin 95. HMSO, London.

Ystaas, J., and O. Frøynes. 1997. Young sweet cherry trees respond favourably to phosphorus fertilization. Acta Horticulturae 448: 383-388.

Andy Moffat (corresponding author)

Environmental and Human Sciences Division

Forest Research

Alice Holt Lodge

Farnham

Surrey, GU10 4LH, U.K.

andy.moffat@forestry.gsi.gov.uk

Kirsten Foot

Environment Agency

Rio House

Waterside Drive

Aztec West, Almondsbury

Bristol, BS32 4UD, U.K.

Fiona Kennedy

Environmental and Human Sciences Division

Forest Research

Alice Holt Lodge

Farnham

Surrey, GU10 4LH, U.K.

Martin Dobson

Current address:

Martin Dobson Associates

Ivy House

49 Liphook Road

Whitehill, Bordon

Hampshire, GU35 9DA, U.K.

Geoff Morgan

Biometrics, Surveys and Statistics Division

Forest Research

Alice Holt Lodge

Farnham

Surrey, GU10 4LH, U.K.
Résumé. Une série d'expériences ont été mises au point en Angleterre au début des années 90 sur cinq sites fermés de dépôt de matières qui ont été conçus selon des normes modernes d'ingénierie, et ce afin de tester la performance relative de 14 espèces forestières indigènes et non indigènes. Cet article décrit les résultats du suivi de leur taux de survie, de croissance et de nutrition sur une période de 10 ans. Les expériences ont démontré qua la plupart des espèces, notamment le frêne, le sorbier, le peuplier blanc et le cerisier sauvage peuvent généralement s'établir sur des sites de dépôt avec des taux de survie comparables aux autres types de sites. En dépit de l'infertilité générale du site, la croissance de plusieurs espèces d'arbres - par exemple le frêne, le hêtre, le chêne anglais, le sycamore, l'aulne italien, l'érable argenté, le peuplier blanc et le sorbier - était similaire à celle attendue au sein d'espaces verts situés dans la localité où le site de dépôt était situé. Tout comme l'infertilité, la sécheresse du sol et le broutage par les mammifères ont été identifiés comme limitant la performance des arbres de certaines espèces, en particulier sur certains sites. Après 10 ans, il n'y avait pas d'indice évident d'interaction entre les systèmes de confinement du dépôt et les gaz provenant du dépôt.

Zusammenfassung. In den frühen 90er Jahren wurden in England eine Reihe von Experimenten gestartet, um die Entwicklung von 14 nativen und eingebürgerten Baumarten auf 5 Standorten mit Bodenverfüllung nach neuesten Standarts zu testen. Diese Studie beschreibt die Ergebnisse der zehnjährigen Überwachung des Wachstums, Überlebens und der Nährstoffversorung. Das Experiment demonstriert, dass einige Arten, besonders Esche, Hainbuche, Weißpappel und Wildkirsche auf diesen Standorten für gewöhnlich gute Überlebensraten zeigen, vergleichbar mit anderen vegetationsfreien Standorten. Ungeachtet der allgemeinen Standortunfruchtbarkeit war das Wachstum vieler Bäume (z.B. Esche, Buche, Eiche, Ahorn, Erle, Silberahorn, Weißpappel und Hainbuche) ähnlich dem erwarteten Wachstum in den grünen Bereichen des rückverfüllten Standorts. Wie auch die Unfruchtbarkeit, wurde auch die Bodentrockenheit und der Wildverbiss als limitierende Faktoren für die Entwicklung bestimmter Arten auf einigen Standorten identifiziert. Nach zehn Jahren gab es keine Anzeichen von Interaktionen mit den Inhalten oder Gasen aus der Bodenverfüllung.

Resumen. En los 90s, se llevaron a cabo una serie de experimentos en Inglaterra, en cinco sitios preparados con estándares modernos, para probar la respuesta relativa de catorce especies de árboles nativos y exóticos. Este reporte describe los resultados del monitoreo de su supervivencia, crecimiento y nutrición en un período de diez años. Los experimentos demostraron que varias especies, notablemente encino, chopo blanco y cerezo silvestre pueden ser establecidos comúnmente en sitios de relleno con tasas de supervivencia comparables a otros lugares. A pesar de la infertilidad general del sitio, el crecimiento de muchas especies de árboles (por ejemplo fresno, haya, encino inglés, sicomoro, aliso italiano, maple y chopo blanco) fue similar al esperado en sitios silvestres. Así también, la infertilidad, la resequedad del suelo y el ramoneo fueron identificados como limitantes para los árboles de especies particulares en algunos sitios. Después de diez años, no hubo evidencia de la interacción con los sistemas de contenedor o rellenos con gas. 